\title{
Homogeneity of the I6S rDNA sequence among geographically disparate isolates of Taylorella equigenitalis
}

\author{
M Matsuda*3, A Tazumi³, S Kagawa ${ }^{3}$, T Sekizuka3 ${ }^{3}$ O Murayama ${ }^{3}$, JE Moore ${ }^{1}$ \\ and BC Millar ${ }^{1,2}$
}

\begin{abstract}
Address: ${ }^{1}$ Department of Bacteriology, Northern Ireland Public Health Laboratory, Belfast City Hospital, Belfast BT9 7AD, Northern Ireland, UK., ${ }^{2}$ School of Biomedical Sciences, University of Ulster, Cromore Road, Coleraine, Co. Londonderry, BT52 1SA, Northern Ireland, UK. and ${ }^{3}$ Laboratory of Molecular Biology, School of Environmental Health Sciences, Azabu University, Fuchinobe 1-17-71, Sagamihara 229-8501, Japan.

Email: M Matsuda* - matsuda@azabu-u.ac.jp; A Tazumi - matsuda@azabu-u.ac.jp; S Kagawa - matsuda@azabu-u.ac.jp;

T Sekizuka - matsuda@azabu-u.ac.jp; O Murayama - matsuda@azabu-u.ac.jp; JE Moore - jemoore@niphl.dnet.co.uk; BC Millar - bcmillar@niphl.dnet.co.uk

* Corresponding author
\end{abstract}

Published: 06 January 2006

BMC Veterinary Research 2006, 2:I doi:10.1/86/1746-6148-2-I
Received: 10 June 2005

Accepted: 06 January 2006

This article is available from: http://www.biomedcentral.com/|746-6/48/2/I

(C) 2006 Matsuda et al; licensee BioMed Central Ltd.

This is an Open Access article distributed under the terms of the Creative Commons Attribution License (http://creativecommons.org/licenses/by/2.0), which permits unrestricted use, distribution, and reproduction in any medium, provided the original work is properly cited.

\begin{abstract}
Background: At present, six accessible sequences of I6S rDNA from Taylorella equigenitalis ( $T$. equigenitalis) are available, whose sequence differences occur at a few nucleotide positions. Thus it is important to determine these sequences from additional strains in other countries, if possible, in order to clarify any anomalies regarding $16 \mathrm{~S}$ rDNA sequence heterogeneity. Here, we clone and sequence the approximate full-length $16 \mathrm{~S}$ rDNA from additional strains of $T$. equigenitalis isolated in Japan, Australia and France and compare these sequences to the existing published sequences.

Results: Clarification of any anomalies regarding I6S rDNA sequence heterogeneity of $T$. equigenitalis was carried out. When cloning, sequencing and comparison of the approximate fulllength $16 \mathrm{~S}$ rDNA from 17 strains of $T$. equigenitalis isolated in Japan, Australia and France, nucleotide sequence differences were demonstrated at the six loci in the 1,469 nucleotide sequence. Moreover, 12 polymorphic sites occurred among 23 sequences of the 16S rDNA, including the six reference sequences.
\end{abstract}

Conclusion: High sequence similarity ( $99.5 \%$ or more) was observed throughout, except from nucleotide positions I 38 to 50 I where substitutions and deletions were noted.

\section{Background}

Contagious equine metritis (CEM), which was first reported in thoroughbred mares during the 1977 breeding season in the UK [1], is an important bacterial genital infectious disease of horses caused by Taylorella equigenitalis. CEM generally leads to a loss of fertility in mares and the disruption of breeding programs. Since the first report of CEM, this disease and its causative agent have been detected in many countries and in various breeds of horses [2,3]. Diagnosis of CEM has been performed by the isolation of $T$. equigenitalis, a nonmotile gram-negative coccobacillus, cultured by means of conventional selective bacteriological techniques.

In relation to the phylogenetic positioning of T. equigenitalis, Bleumink-Pluym et al. were the first to determine $16 \mathrm{~S}$ rDNA sequences from three strains of $T$. equigenitalis (NCTC11184 ${ }^{\mathrm{T}}$, N480/82 and N610/88; GenBank Acces- 
sion No. $\underline{\mathrm{X} 68645}$ ) to be identical and demonstrated this organism to belong to the $\beta$ subclass of the class Proteobacteria [4]. When Jang et al. analyzed the phylogenetic position of T. asinigenitalis, which is a new second species within the genus Taylorella, and a gram-negative, nonmotile coccobacilli but phenotypically indistinguishable from $T$. equigenitalis, which was isolated from donkey jacks (Equus asinus) in the USA, in 1997 and 1998 [5], they described that T. equigenitalis appears to be homogeneous with respect to the 16S rDNA sequence, since all 15 strains, (11 American strains, two Dutch strains, one British and one Japanese isolate, (Accession No. AF297712 for a Dutch isolate 10783; AF297173 for an American isolate 96-178), together with the published sequence (X68645), were 100\% identical [6].

Recently, our research group determined the $16 \mathrm{~S}$ rDNA sequences of three additional strains, a British type strain NCTC11184 ${ }^{\mathrm{T}}$, an American prototype strain Kentucky 188 and a Japanese strain EQ59 of T. equigentalis, and demonstrated sequence differences in the six 16S rDNA sequences including three reference sequences, whose accession numbers are shown in Table 1 [7]. Consequently, at present, six accessible sequences of 16S rDNA from $T$. equigenitalis, whose sequence differences occur at a few nucleotide positions are available.

Therefore, it is important to determine these sequences from additional strains in other countries, if possible, in order to clarify any anomalies regarding 16S rDNA sequence heterogeneity. Therefore, the authors wished to clone and sequence the approximately full-length $16 \mathrm{~S}$ rDNA from more strains of $T$. equigenitalis isolated in Japan, Australia and France and compare these sequences among the existing published sequences described above.

\section{Results}

As shown in Table 2 [see 1], the nucleotide sequence differences were demonstrated at six loci in the 1469 nucleotide sequence of the nearly full-length 16S rDNA, among 17 strains (EQ70 Fr-10) isolated in Japan, Australia and France (AB200397-AB200413 in Table 1). Moreover, 12 polymorphic sites occurred among 23 sequences of the $16 \mathrm{~S}$ rDNA, including the six reference sequences, as demonstrated in Table 2. In relation to the three countries, Japan, Australia and France, the strains from each respective country, interestingly, gave an identical sequence. Moreover, these strains whose $16 \mathrm{~S}$ rDNA sequences were analyzed, are from all over the world and carried distinct multiple genotypes [3]. In addition, the sequences of two American strains (Kentucky 188 and 96-178 [AF 297173]) used as references in the present study are different on some positions.
Consequently, in the present study, a high sequence similarity of $16 \mathrm{~S}$ rDNA $(99.5 \%$ or more) with the nine polymorphic sites was observed, between np 138 and 501, of a total of 12 , where substitutions and deletions were noted. Thus, there is a single polymorphic site in the approximately $2 / 3$ of the $16 \mathrm{~S}$ rDNA sequence between $\mathrm{np}$ 502 and 1469, while the first approximately $1 / 3$ between np 1 and 501 has nine polymorphic sites among 17 strains, suggesting an extremely high sequence similarity in the approximately $2 / 3$ downstream of the 16S rDNA sequence of $T$. equigenitalis.

\section{Discussion}

Recently, Jang et al. demonstrated that the 16S rDNA of $T$. equigenitalis gave $97.6 \%$ sequence similarity to those of $T$. asinigenitalis [6]. In relation to one of the present molecular guidelines, it is suggested that 3\% sequence variation of the 16S rDNA sequence is a threshold value to represent distinctly different bacterial species [8-11] However, most recently, some examples of lower levels of $16 \mathrm{~S}$ rDNA sequence variations were found among some Campylobacter species [12]. The organisms within the genus Taylorella are also an example of lower levels of $16 \mathrm{~S}$ rDNA sequence variation.

\section{Conclusion}

The 16S rDNA sequences of T. equigenitalis were demonstrated to give high sequence similarity ( $99.5 \%$ or more) to each other among 23 sequences, but were not identical. Lower levels of 16S rDNA sequence variations were confirmed among the organisms of the genus Taylorella.

\section{Methods \\ T. equigenitalis strains}

Seventeen strains of T. equigenitalis, which had been isolated in Japan $(n=6)$, Australia $(n=7)$ and France $(n=4)$ and examined in the present study are shown in Table 1 [see Additional File 1]. Although six Japanese strains, seven Australian strains and a French strains (Fr-10) were isolated from mares clinically affected with CEM, sources and symptom of the two French strains (Fr- 1 and Fr-2) are not available. Since male horses were demonstrated to transmit the organism responsible for CEM, in the present study an isolate isolated from a symptomless carrier male French Trotter (Fr-9) was also examined (Table 1) [see Additional file 1].

\section{Cultural conditions and genomic DNA preparation}

Culture conditions for these strains and genomic DNA preparation have been described previously $[13,14]$.

\section{PCR amplification, cloning and sequencing}

PCR amplification, cloning and sequencing of the nearly full-length 16S rDNA have also been described [15]. In relation to the PCR, at present, a primer pair set (fD1; 5'- 
GAATTTGATCCTGGCTCAG-3' and rTel; 5'-GGCTACCTTGTTACGACTT-3') was employed for amplification of the nearly full-length $16 \mathrm{~S}$ rDNA from $T$. equigenitalis strains. The primer fD1 contained the 3' end-19 nucleotide sequences of the original fD1 primer sequence [16]. The rTel was constructed based on the nucleotide sequence information of the 3' end region of E. coli 16S rDNA of rrnB operon (DDBJ/EMBL/GenBank Accession No. Ј01695).

\section{Nucleotide sequence analysis}

The sequences of the nearly full-length 16S rDNA were aligned using GENETYX-MAC version 9.0 (GENETYX Co. Tokyo, Japan). The sequence data of the 16S rDNA of $T$. equigenitalis determined in the present study are accessible in the DDBJ/EMBL/GenBank, as shown in Table 1, as well as the six reference sequences.

The nucleotide sequences corresponding to the primers fD1 and rTel, employed for PCR amplification of the nearly full-length 16S rDNA from the 17 strains of T. equigenitalis, were excluded for similarity analysis. Therefore, the nucleotide position (np) one (A) of the sequence data shown in the DDBJ/EMBL/GenBank corresponds to np 28 of the sequence of the 16S rRNA gene from the $\mathrm{rrnB}$ cistron of Escherichia coli $[17,18]$. As already described [7], in the three reference sequences from NCTC11184T, Kentucky 188 and EQ59, CCTCCT sequences (np 1513 to 1518), which are highly conserved sequences close to the 3 ' end of the mature 16S rRNA and complementary to the Shine-Dalgarno sequence on mRNA [19-21], [22] were demonstrated.

\section{List of abbreviations used}

Abbreviation: CEM, contagious equine equigenitalis metritis, T. equigenitalis, Taylorella equigenitalis; rDNA, ribosomal DNA

\section{Authors' contributions}

MM participated in design of the study, collected strains, drafted the manuscript and review of the manuscript. AT, SK and TS were involved with cloning, sequencing and analysis of the $16 \mathrm{~S}$ rDNA sequences from $T$. equigenitalis strains. OM, JEM and BCM participated in its design and coordination, and review of the manuscript.

\section{Additional material}

\section{Additional File 2}

Table 1

Click here for file

[http://www.biomedcentral.com/content/supplementary/17466148-2-1-S2.xls]

\section{Additional File 1}

Table 2

Click here for file

[http://www.biomedcentral.com/content/supplementary/17466148-2-1-S1.xls]

\section{Acknowledgements}

The authors wish to thank Dr. T. Anzai, Epizootic Research Station, Equine Research Institute, Japan Racing Association, Japan, Dr. M. Barton, School of Pharmacy and Medical Science, University of South Australia, Australia and Dr. F. Klein, Laboratoire Départemental de L'Orne, France for the provision of $T$. equigenitalis strains used in the present study.

\section{References}

I. Crowhurst RC: Genital infection in mares. Vet Rec 1977, 100:476.

2. Ter Laak EA, Fennema G, Jaartsveld FHJ: Contagious equine metritis in the Netherlands. Ti jdschr Diergeneeskd 1989, I 14:189-20I.

3. Matsuda M, Moore JE: Recent advances in molecular epidemiology and detection of Taylorella equigenitalis associated with contagious equine metritis (CEM). Vet Microbiol 2003, 97: III-122.

4. Bleumink-Pluym NMC, van Dijk L, van Vliet AHM, van der Giessen JWB, van der Zeijst BAM: Phylogenetic position of Taylorella equigenitalis determined by analysis of amplified $16 \mathrm{~S}$ ribosomal DNA sequences. Int J Syst Bacteriol 1993, 43:618-621.

5. Katz JB, Evans LE, Hutto DL, Schroeder-Tucker LC, Carew AM, Donahue JM, Hirsh DC: Clinical, bacteriologic serologic, and pathologic features of infections with atypical Taylorella equigenitalis in mares. J Am Vet Assoc 2000, 21 6:1945-1948.

6. Jang SS, Donahue JM, Arata AB, Goris J, Hansen LM, Earley DL, Vandamme PAR, Timoney PJ, Hirsh DC: Taylorella asinigenitalis sp. nov. a bacterium isolated from the genital tract of male donkeys (Equus asinus). Int J Syst Evol Microbiol 200I, 5 I:971-976.

7. Kagawa S, Nagano Y, Tazumi A, Murayama O, Millar BC, Moore JE, Mastuda M: Nucleotide sequencing and analysis of 165 rDNA and I6S-23S rDNA internal spacer region (ISR) of Taylorella equigenitalis. Vet Res Commun 2005 in press.

8. Fox GE, Wisotzkey JD, Jurtshuk P Jr: How close is close: I6S rRNA sequence identity may not be sufficient to guarantee species identity. Int J Syst Bacteriol I992, 42:166-I70.

9. Stackebrandt E, Goebel BM: Taxonomic note: a place for DNADNA reassociation and I6S rRNA sequence analysis in the present species definition in bacteriology. Int J Syst Bacteriol 1994, 44:864-849.

10. Clayton RA, Sutton G, Hinkle PS Jr, Bult C, Fields C: Intraspecific variation in small-subunit rRNA sequences in GenBank: why single sequences may not adequately represent prokaryotic taxa. Int J Syst Bcateriol 1995, 45:595-599.

II. Kolbert CP, Persing DH: Ribosomal DNA sequencing as a tool for identification of bacterial pathogens. Curr Microbiol 1999, 2:229-305.

12. Gorkiewicz G, Feierl G, Schober C, Dieber F, Köfer J, Zechner R, Zechner EL: Species-specific identification of Campylobacters by partial I6S rRNA gene sequencing. J Clin Micrpbiol 2003, 41:2537-2546.

13. Miyazawa T, Mastuda M, Isayama $Y$, Samata $T$, Ishida $Y$, Ogawa $S$, Takei K, Honda M, Kamada M: Genotyping of strains of Taylotrlla equignitalis from thoroughbed brood mares in Japan. Vet Res Commun 1995, 19:265-27I.

14. Kagawa S, Moore JE, Murayama O, Mastuda M: Comparison of the value of pulsed-field gel electrophoresis, random amplified polymorphic-field gel electrophoresis, random amplified polymorphic DNA and amplified rDNA restriction analysis for subtyping Taylorella equigenitalis. Vet Res Commun 200I, 25:26I-269.

15. Miyajima M, Matsuda M, Haga S, Kagawa S, Millar BC, Moore JE: Cloning and sequenceing of I6S rDNA and I6S-23S rDNA inter- 
nal spacer region (ISR) from urease-positive thermophilic Campylobacter (UPTC). Lett Appl Microbiol 2002, 34:287-289.

16. Weisburg WG, Barns SM, Pelletier DA, Lane DJ: I6S ribosomal DNA amplification for phylogenetic study. J Bacteriol I99I, 1 73:697-703.

17. Brosius J, Palmer M, Kennedy PJ, Noller HF: Complete nucleotide sequence of a 165 ribosomal RNA gene from Escherichia coli. Proc Natl Acad Sci USA 1978, 75:480 I-4805.

18. Brosius J, Dull TJ, Sleeter DD, Noller HF: Gene organization andprimary structure of a ribosomal RNA operon from Escherichia coli. J Mol Biol I98I, I48:107-I27.

19. Steitz JA: Genetic signals and nucleotide sequence in messenger RNA. In biological regulation and development l, gene expression Edited by: Goldberg RF. NY: Plenum Publishing Corporation; 1979:349-389.

20. Benjamin L: Genes VII Oxford University Press Inc. New York; 2000. Ofengand J, Denman R, Negro D, Krzyzosiak W, Nurs K, Colgan J: Structural and functional relationships at the decoding site of the $\mathrm{E}$. coli ribosome. In structure and expression from proteins to ribosomes. ed. Sarma RH and Sarma MH, New York, Adenine Press. pp. 209-228

21. Stiege W, Stade K, Schuler D: Brimacombe R. Covalent crosslinking of poly (A) to Escherichia coli ribosomes, and localization of the cross-link site within I6S RNA. Nucleic Acids Res 1988, 16:2369-2388.

Publish with Bio Med Central and every scientist can read your work free of charge

"BioMed Central will be the most significant development for disseminating the results of biomedical research in our lifetime. "

Sir Paul Nurse, Cancer Research UK

Your research papers will be:

- available free of charge to the entire biomedical community

- peer reviewed and published immediately upon acceptance

- cited in PubMed and archived on PubMed Central

- yours - you keep the copyright

Submit your manuscript here:

http://www.biomedcentral.com/info/publishing_adv.asp 